\title{
Bismuth subsalicylate as filler particle for an experimental epoxy-based root canal sealer
}

\author{
Eduardo Schwartzer', Bruna Genari', Fabrício Mezzomo Collares'1, Vicente Castelo Branco Leitune', \\ Fabrício Aulo Ogliari², Susana Maria Werner Samuel ${ }^{1}$ \\ ${ }^{1}$ Dental Materials Laboratory, School of Dentistry, Federal University of Rio Grande do Sul, Porto Alegre, RS, Brazil \\ ${ }^{2}$ School of Engineering, Federal University of Pelotas, Pelotas, RS, Brazil
}

Received for publication: May 28, 2013 Accepted: September 13, 2013

Correspondence to: Fabrício MezzomoCollares Rua Ramiro Barcelos, 2492, CEP: 90035-003 Rio Branco, Porto Alegre, RS, Brasil Phone: +555133085198 E-mail: fabricio.collares@ufrgs.br

\begin{abstract}
Aim: To evaluate the influence of bismuth subsalicylate addition in different concentrations on theproperties ofan experimental epoxy-based root canal sealer. Methods: Bismuth subsalicylate in $20 \%, 40 \%, 60 \%, 80 \%, 100 \%$ and $120 \mathrm{wt} \%$ was added tothe sealer. Flow, film thickness, working time, setting time, dimensional change, sorption, solubility and cytotoxicity were evaluated according to ISO standard. Data were statistically analyzed by one-way ANOVA and Tukey'stest with a significance level of $5 \%$ for all tests. Results: The flow, working and setting times significantly decreased withincreasing particle concentration. The film thickness, dimensional change, water sorption and solubility values significantly increased with higher particle amount. The results for cytotoxicity showed no statistically significant differences among the particle proportions. Conclusions: The results suggest that the addition up to $80 \%$ wt of bismuth subsalicylate appears to be a promising filler particle to root canal sealer development.
\end{abstract}

Keywords: root canal, cement, endodontics, bismuth subsalicylate.

\section{Introduction}

Root canal filling is an important step in endodontic therapy after appropriate shaping and cleaning of the canals to seal off the root canal system of any irritants that remain after enlargement ${ }^{1}$. New root canal sealers have been developed to improve properties like sealing, solubility and dimensional stability $^{2-4}$. These materials are composed, in general, by a main organic component $t^{5}$ and inorganic elements such as radiopacifiersand filler particles, such as bismuth compounds ${ }^{6}$.

Bismuth is a chemical element with different applications ${ }^{7}$. In medicine, bismuth compounds such as bismuth subsalicylate can be used for the treatment of various gastrointestinal illnesses ${ }^{8-10}$. In Dentistry, bismuth compounds (e.g. bismuth oxide)provide an acceptable radiopacity to root canal sealers ${ }^{6,11-12}$. Considering that resin-based endodontic sealers present good physical properties and ensure adequate biological performance ${ }^{2-3}$, bismuth subsalicylate should be studied.

The aim of this study was to evaluate the influence of bismuth subsalicylate addition in different concentrations into an experimental epoxy-based root canal sealer regarding the flow, film thickness, working time, setting time, dimensional change, sorption and solubility and cytotoxicity of an experimental epoxy-based root canal sealer. 


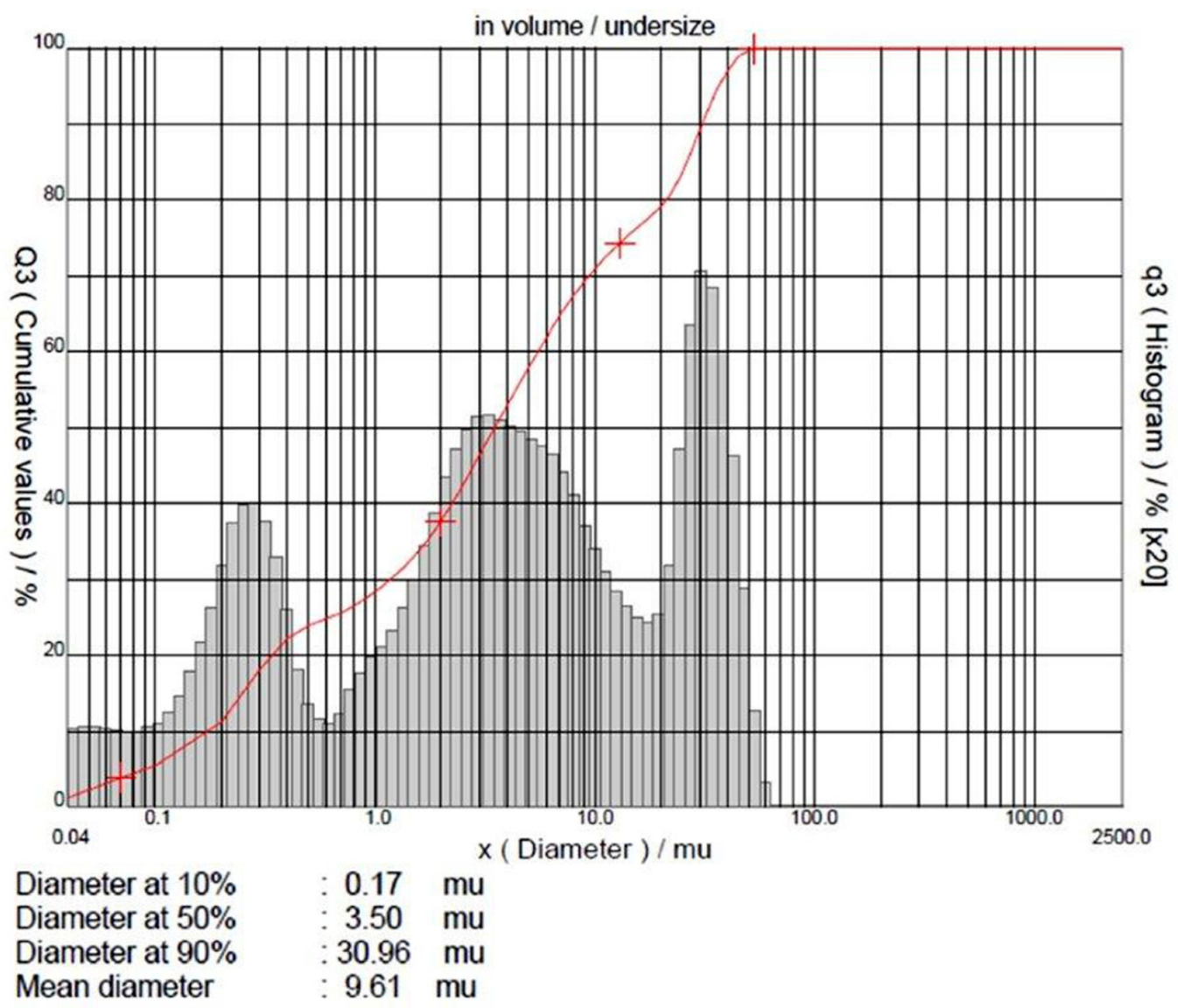

Fig. 1.The particle size distribution of bismuth subsalicylate particle.

\section{Material and methods}

\section{Experimental Sealer Formulation}

An experimental epoxy-based root canal sealer containing bisphenol-A and epichlohydrin, (Fiberglass, Porto Alegre, RS, Brazil) at 2:1 (base: catalyst) was used in this study. To this sealer was added bismuth subsalicylate in several concentrations: $20 \%, 40 \%, 60 \%, 80 \%, 100 \%$ and $120 \%$, in weight. The particle size distribution was assessed using a laser diffraction particle size analyzer (CILAS 1180, Orleans, France). The mean diameter particle was $9.61 \mu \mathrm{m}$ and particle size distribution is shown in Figure 1. Colloidal silica (particle diameter of $7 \mathrm{~nm}$ ) was added at $0.05 \mathrm{wt} \%$ to adjust the viscosity of the sealers.

\section{Flow}

The flow test was conducted in accordance with ISO $6876^{13}$. A total of $0.05 \mathrm{~mL}$ of each experimental sealer was placed on a glass plate $(40 \times 40 \times 5 \mathrm{~mm})$ with a graduated syringe $(1.5 \mathrm{~mL})$. Another plate with a mass of $20 \pm 2 \mathrm{~g}$ and a load of $100 \mathrm{~g}$ was applied on top of the material. Ten minutes after the start of mixing, the load was removed, and the major and minor diameters of the compressed material were measured using a digital caliper (Digimess, São Paulo,
SP,Brazil). For each experimental group, the test was conducted three times and the mean value was recorded.

\section{Film thickness}

This evaluation was made according to ISO $6876^{13}$. Two glass plates $(5 \times 10 \mathrm{~mm})$ were placed together and their combined thickness was measured. An amount of $0.5 \mathrm{~mL}$ of experimental sealer was placed at the center of one of the plates, and a second plate was placed on top of the material. At $180 \pm 5$ s after the start of mixing, a load of $150 \pm 3 \mathrm{~N}$ was applied vertically onto the top glass plate. Ten minutes after the start of mixing, the thickness of the two glass plates and the interposed sealer film was measured using a digital caliper. The film thickness was recorded by the difference between the thickness of the two glass plates with and without sealer. The mean value of three measurements was recorded as the film thickness of the material.

\section{Working time}

The test to measure the time to mix the components to obtain the cement with appropriate properties was based in ISO $6876^{13}$. This test had the same sequence of the flow test, but it was repeated at longer time intervals between manipulation and setting time. The working time was 
recorded when the diameter of the specimen were $10 \%$ lowerthan the diameter of the immediate manipulated cement. The test was repeated three times and the mean values were recorded.

\section{Setting time}

The setting time was recorded according to ISO $6876^{13}$. Rings measuring $10 \mathrm{~mm}$ in diameter and $1 \mathrm{~mm}$ in height were filled with the material. These specimens were maintained under controlled temperature and humidity conditions, $37 \pm 1{ }^{\circ} \mathrm{C}$ and $95 \%$ respectively. Measurements were conducted using Gilmore needles, weighing $100 \pm 0.5 \mathrm{~g}$ and a flat end of $2.0 \pm 0.1 \mathrm{~mm}$ diameter. The needle was lowered vertically onto the horizontal surface of each sample in such a way that it touched the surface every $5 \mathrm{~min}$. The setting time was recorded when the needle did not produce any visible indentation on the sealer surface.

\section{Dimensional change following setting}

The dimensional change was measured based in ISO $6876^{13}$. The cylindrical matrixes were filled with the sealer. These specimens were positioned between two glass plates $(25 \times 70 \times 1 \mathrm{~mm})$. Five minutes after the start of mixing, the specimens were placed in desiccators at $37^{\circ} \mathrm{C}$ and $95 \%$ relative humidity and held for a period three times the setting time. The specimens were removed from the matrixes and the thickness was measured. Then, they were immersed in distilled water at $37^{\circ} \mathrm{C}$ during 30 days and a new measurement was made. A micrometer (Aus-JENA, Jena, Germany) with $0.001 \mathrm{~mm}$ accuracy was used for measuring purposes. The difference between before and after storage was calculated. Measurements were made three times and the mean value of these measurements was recorded as the dimensional change of the material.

\section{Water sorption and solubility}

Water sorption and solubility were determined based on the ISO $4049^{14}$. Root canal sealer disks were produced in a silicone matrix (10.0mm diameter, $1.0 \mathrm{~mm}$ thick). Specimens were placed in a desiccator at $37^{\circ} \mathrm{C}$ for 22 hand in a desiccator at $23^{\circ} \mathrm{C}$ for $2 \mathrm{~h}$. The disks were repeatedly weighed in an analytical balance (Shimadzu Corp., Tokyo, Japan) until a constant mass $\left(m_{1}\right)$ was obtained (i.e., until the mass variance of each specimen was no more than $0.1 \mathrm{mg}$ in any $24 \mathrm{~h}$ period).
Diameter and thickness of each specimen were measured with a digital caliper to calculate the volume (V) of each disk (in $\left.\mathrm{mm}^{3}\right)$. Thereafter, the specimens were stored in sealed glass vials with $10 \mathrm{~mL}$ of distilled water at $37^{\circ} \mathrm{C}$ for seven days. After 7days, the disks were weighed after being washed under running tap water and gently wiped with an absorbent paper to obtain themass $\left(\mathrm{m}_{2}\right)$ and then returned to the desiccator. Next, the specimens were weighed until a constant mass $\left(\mathrm{m}_{3}\right)$ was obtained (as described for $\mathrm{m}_{1}$ ). Water sorption (WS) and solubility (SL), in micrograms per cubic millimeter, were calculated using the following formulae:

$$
\begin{aligned}
& \mathrm{WS}=m_{2}-m_{3} / \mathrm{V} \\
& \mathrm{SL}=m_{1}-m_{3} / \mathrm{V}
\end{aligned}
$$

\section{Cytotoxicity}

According to ISO $10993-5^{15}$, the cell viability was analyzed using mononuclear cells obtained from human peripheral blood. These cells were routinely maintained in Dulbecco's modified Eagle's medium (DMEM) with HEPES - HDMEM, with 10\% fetal calf serum. The cells were maintained with endodontic sealers incubated for $72 \mathrm{~h}$ at $37^{\circ} \mathrm{C}$ and $5 \% \mathrm{CO}_{2}$. The controls consisted of cells incubated without endodontic cement. The rate of viable cells was quantified by testing(3-4,5dimethylthiazol-2-yl)-2,5-diphenol tetrazoliumbromide) MTT assay after 24 hin contact with the endodontic cement.

\section{Statistical analysis}

Data normality distribution was analyzed by KolmogorovSmirnov and the tests used in this study were one-way ANOVA and Tukey's multiple-comparison test with a significance level of $5 \%$ for all tests.

\section{Results}

\section{Flow}

The flow significantly decreased with increasing filler particles concentration comparing $20 \%$ and $40 \%$ with the other percentages $(\mathrm{p}<0.05)$, ranging from 15.13 to $21.72 \mathrm{~mm}$. The results of flow measurements are set out in Table 1.

\section{Film thickness}

The film thickness values significantly increased with increasing filler particle concentration $(p<0.05)$, ranging from

Table 1. Flow, film thickness, working time and setting time of the sealers with bismuth subsalicylate in different proportions.

\begin{tabular}{llccc}
\hline Flow $(\mathrm{mm})$ & $\begin{array}{c}\text { Film thickness } \\
(\mu \mathrm{m})\end{array}$ & $\begin{array}{c}\text { Working time } \\
(\mathrm{min})\end{array}$ & $\begin{array}{c}\text { Setting time } \\
(\mathrm{h})\end{array}$ \\
$\mathbf{2 0 \%}$ & $21.72(0.36)^{\mathrm{a}}$ & $113(20.8)^{\mathrm{e}}$ & $53.33(01.15)^{\mathrm{a}}$ & $06: 35(00: 27)^{\mathrm{a}}$ \\
$\mathbf{4 0 \%}$ & $20.9(0.84)^{\mathrm{a}}$ & $173(15.3)^{\mathrm{d}}$ & $48.33(01.15)^{\mathrm{b}}$ & $06: 31(00: 15)^{\mathrm{a}}$ \\
$\mathbf{6 0 \%}$ & $18.69(0.54)^{\mathrm{b}}$ & $223(20.8)^{\mathrm{d}}$ & $48.67(01.15)^{\mathrm{b}}$ & $06: 15(00: 18)^{\mathrm{a}, \mathrm{b}}$ \\
$\mathbf{8 0 \%}$ & $17.16(0.43)^{\mathrm{c}}$ & $333(11.5)^{\mathrm{c}}$ & $40.33(01.15)^{\mathrm{c}}$ & $05: 25(00: 20)^{\mathrm{b}}$ \\
$\mathbf{1 0 0 \%}$ & $16.30(0.55)^{\mathrm{c}}$ & $400(20)^{\mathrm{b}}$ & $32.00(01.73)^{\mathrm{d}}$ & $04: 17(00: 17)^{\mathrm{c}}$ \\
$\mathbf{1 2 0 \%}$ & $15.13(0.37)^{\mathrm{c}}$ & $483(20.8)^{\mathrm{a}}$ & $25.67(01.15)^{\mathrm{e}}$ & $03: 51(00: 12)^{\mathrm{c}}$ \\
\hline
\end{tabular}

Different letters in same column represent statistically significant differences $(p<0.05)$. 
Table 2. Dimensional change, sorption, solubility and radiopacity of the sealers with bismuth subsalicylate in different proportions.

\begin{tabular}{lccc}
\hline & Dimensional change (\%) & Sorption $\left(\mu \mathrm{g} / \mathrm{mm}^{3}\right)$ & Solubility $\left(\mu \mathrm{g} / \mathrm{mm}^{3}\right)$ \\
$\mathbf{2 0 \%}$ & $-0.14(0.02)^{\mathrm{a}}$ & $33.85(4.81)^{\mathrm{e}}$ & $13.19(6.33)^{\mathrm{c}}$ \\
$\mathbf{4 0 \%}$ & $-0.31(0.14)^{\mathrm{b}}$ & $44.02(6.42)^{\mathrm{d}, \mathrm{e}}$ & $18.4(5.05)^{\mathrm{b}, \mathrm{c}}$ \\
$\mathbf{6 0 \%}$ & $-0.57(0.06)^{\mathrm{b}}$ & $59.12(9.67)^{\mathrm{c}, \mathrm{d}}$ & $22.96(1.15)^{\mathrm{b}}$ \\
$\mathbf{8 0 \%}$ & $-0.75(0.04)^{\mathrm{c}}$ & $69.55(5.36)^{\mathrm{c}}$ & $23.62(6.01)^{\mathrm{b}}$ \\
$100 \%$ & $*$ & $123.17(7.36)^{\mathrm{b}}$ & $21.47(2.83)^{\mathrm{b}, \mathrm{c}}$ \\
$\mathbf{1 2 0 \%}$ & $*$ & $177.9(15.22)^{\mathrm{a}}$ & $39.45(3.23)^{\mathrm{a}}$ \\
\hline
\end{tabular}

${ }^{*}$ It was not possible to evaluate because of disintegrationof the specimens.

Different letters in the same column represent statistically significant differences $(p<0.05)$.

113 to $483 \mu \mathrm{m}$. The film thickness measurements are shown in Table 1.

\section{Working time}

The means and standard deviations of working time are shown in Table 1. The working time significantly decreased with increasing filler particle concentration $(p<0.05)$, ranging from 53.3 to $25.67 \mathrm{~min}$.

\section{Setting time}

The setting time significantly decreased with increasing filler particle concentration $(p<0.05)$. These values varied from $03: 51$ to $06: 35 \mathrm{~h}$. The setting time measurements are shown in Table 1.

\section{Dimensional change following setting}

The means and standard deviations of the dimensional change are shown in Table 2. The significantly highest dimensional change occurred with $80 \%$ filler particle concentration and the lowest was with $20 \%$. The values ranged from -0.14 to $-0.75 \%$. The specimens of the groups with 100 and $120 \mathrm{wt} \%$ of filler particles were solubilized and the dimensional change measurement could not be performed.

\section{Water sorption and solubility}

Water sorption and solubility means and standard deviations are shown in Table 2. Water sorption significantly increased with higher addition of filler particle concentration $(\mathrm{p}<0.05)$, ranging from 33.85 to $177.9 \mu \mathrm{g} / \mathrm{mm}^{3}$. Solubility of the specimens with $120 \mathrm{wt} \%$ filler particle concentration was statistically higher than groups with other filler particle concentration $(\mathrm{p}<0.05)$. The values of solubility ranged from 13.19 to $39.45 \mu \mathrm{g} / \mathrm{mm}^{3}$.

\section{Cytotoxicity}

There were no statistically significant differences ( $p>0.05)$ amongthe filler particle concentrations regarding cytotoxicity. The results are shown in Figure 2.

\section{Discussion}

In the present study, the addition of bismuth sub salicylate influenced the tested properties. The groups higher than $60 \%$ did not achieve the standards ${ }^{13}$. Previous study

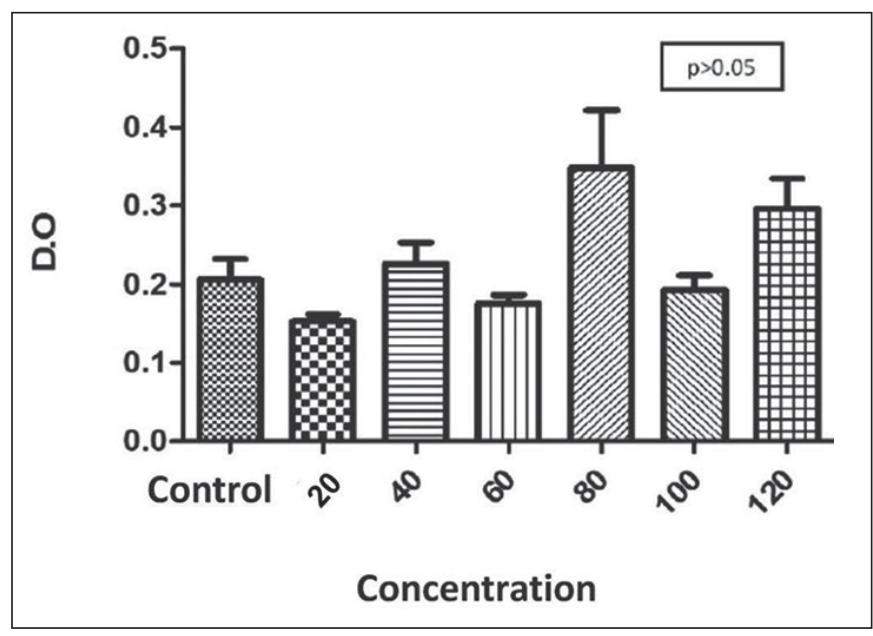

Fig. 2.Cytotoxicity of the sealer with bismuth subsalicylate in different proportions.

that evaluated flow presented values of $8.9 \mathrm{~mm}$ for Gutta flow, $10.9 \mathrm{~mm}$ for $\mathrm{AH}$ Plus and $12.2 \mathrm{~mm}$ for Epiphany ${ }^{16}$. A high flow value could lead to an increased risk of sealer extrusion, but low flow values could difficult the penetration of materials in dentin root canal walls ${ }^{17-18}$. The sealers with bismuth subsalicylate showed higher values than the standard $(50 \mu \mathrm{m})^{13}$. Increased concentration of particles led to an increased volume of sealer particles, decreasing the flow and film thickness of sealer. However, flow and film thickness values of the experimental sealer of the present study are consistent to the values presented by commercial resin-based sealers ${ }^{19}$.The working and setting times must be long enough to manipulate the material to fill adequately the root canal ${ }^{20}$. ISO $6876^{13}$ requires that a sealer should present working timeless than $30 \mathrm{~min}$ and setting time ranged from $30 \mathrm{~min}$ to $72 \mathrm{~h}$. In the present study, the working time of group with $120 \mathrm{wt} \%$ fulfilled the requirement. For the setting time, all groups fulfilled the requirements.

Water sorption could cause hydrolysis and plasticizing of the resin-based materials. These processes could result in the separation of the polymer chains, changing the dimension of the material, and consequently leading to gap formation and fluid infiltration ${ }^{21}$. According to ISO6876 ${ }^{13}$, the endodontic sealer should not shrink more than $1 \%$ and swell more than $0.1 \%$ to avoid gaps between sealer and dentin. In the present study, the experimental endodontic sealers presented swelling higher than $0.1 \%{ }^{13}$ accordingly to commercial available sealers ${ }^{22-24}$. Any uptake of water is 
determined by the intrinsic hydrophilicity of the copolymer, the type and amount of filler particles ${ }^{25}$ and it could result in lower mechanical properties of root canal sealers ${ }^{21,26}$. The water sorption could also lead to degradation of the sealer, due to the unreacted monomers leach through porosities ${ }^{21}$.According to ISO $4049^{14}$, the water sorption of the resin-based material cannot be more than $40 \mu \mathrm{g} / \mathrm{mm}^{3}$ and the water solubility must be up to $7.5 \mu \mathrm{g} / \mathrm{mm}^{3}$. In the present study, the water sorption of the sealers with $20 \mathrm{wt} \%$ of bismuth subsalicylate presented water sorption in accordance to the requirement. The other concentrations did not fulfill the standard. Solubility also presented higher values than required. However, this standard is for restorative materials; there is no specific standard for resin-based root canal sealers. The values of water sorption and solubility are consistent with commercial resin-based root canal sealers ${ }^{27}$. Solubility of unreacted components could lead to cytotoxicity of periapical region tissues ${ }^{21,28}$. Low cytotoxicity is a desirable characteristic for new root canal sealers. In the present study, addition of bismuth subsalicylate did not increase the cytotoxicity of the experimental sealer.

It was concluded that addition up to $80 \%$ wt of bismuth subsalicylate appears to be a promising filler particle for root canal sealer development.

\section{References}

1. Schilder H. Filling Root Canals in Three Dimensions. J Endod. 2006; 32: 281-90.

2. Schwartz RS. Adhesive Dentistry and Endodontics. Part 2: Bonding in the Root Canal System -The Promise and the Problems: A Review. J Endod. 2006;32: 1125-34.

3. Salz U, Poppe D, Sbicego S, Roulet JF. Sealing properties of a new root canal sealer. Int Endod J. 2009; 42: 1084-9.

4. Rosa PCF, Mancini MNG, Camargo SEA, Garrido ADB, Camargo CHR; Rode SM. Dimensional Alterations and Solubility of New Endodontic Sealers. Braz Dent J. 2010; 21: 301-4.

5. Al-Hiyasat AS, Tayyar M, Darmani H. Cytotoxicity evaluation of various resin based root canal sealers. Int Endod J. 2010; 43: 148-53.

6. Collares FM, Ogliari FA, Lima GS, Fontanella VR, Piva E, Samuel SM. Ytterbium trifluoride as a radiopaque agent for dental cements. Int Endod J. 2010; 43: 792-7.

7. Li H, Sun H. Recent advances in bioinorganic chemistry of bismuth (Review). Curr Opin Chem Biol. 2012; 15: 74-83.

8. Andrews PC, Deacon GB, Forsyth CM, Junk PC, Kumar I, Maguire M. Towards a Structural Understanding of the AntiUlcer and Anti-Gastritis Drug Bismuth Subsalicylate. Angew Chem Int Ed Engl. 2006; 45: 5638-42.

9. Chande N, MacDonald JK, McDonald JW. Interventions for treating microscopic colitis: a Cochrane Inflammatory Bowel Disease and Functional Bowel Disorders Review Group systematic review of randomized trials. Am J Gastroenterol. 2009; 104: 235-41.

10. Temmerman F, Baert F. Collagenous and lymphocytic colitis: systematic review and update of the literature. Dig Dis. 2009; 27(Suppl 1): 137-45.

11. Kim EC, Lee BC, Chang HS, Lee W, Hong CU, Min KS. Evaluation of the radiopacity and cytotoxicity of Portland cements containing bismuth oxide. Oral Surg Oral Med Oral Pathol Oral Radiol Endod. 2008; 105: e54-7.
12. Húngaro-Duarte MA, Kadre GDOE, Vivan RR, Tanomaru JMG, Tanomaru Filho M, de Moraes IG. Radiopacity of Portland Cement associated With Different Radiopacifying Agents. J Endod. 2009; 34: 737-40.

13. International Organization for Standardization. Dental Root Canal Sealing Materials. $N^{\circ}$ 6876:2001(E); Second edition.

14. International Organization for Standardization. Dentistry Polymer-based restorative materials. $\mathrm{N}^{\circ}$ 4049:2009(E); Fourth edition.

15. International Organization for Standardization. Biological evaluation of medical devices Part 5: Tests for in vitro cytotoxicity. $\mathrm{N}^{\circ}$ ISO10993-5:2001(E); Third edition.

16. Nawal RR, Parande M, Sehgal R, Naik A, Rao NR.A comparative evaluation of antimicrobial efficacy and flow properties for Epiphany, Gutta flow and AH-Plus sealer. Int Endod J. 2011; 44: 307-13.

17. Gambarini G, Testarelli L, Pongione G, Gerosa R, Gagliani M. Radiographic and rheological properties of a new endodontic sealer. Aust Endod J. 2006; 32: 31-4.

18. Bernardes RA, de Amorim Campelo A, Junior DS, Pereira LO, Duarte MA, Moraes IG, et al. Evaluation of the flow rate of 3 endodontic sealers: Sealer 26, AH Plus, and MTA Obtura. Oral Surg Oral Med Oral Pathol Oral Radiol Endod. 2010; 109: e47-9.

19. Hosoya M, Kurayama H, Iino F, Arai T. Effects of calcium hydroxide on physical and sealing properties of canal sealers. Int Endod J. 2004; 37: 178-84.

20. McMichen FR, Pearson G, Rahbaran S, Gulabivala K. A comparative study of selected physical properties of five rootcanal sealers. Int Endod J. 2003; 36: 629-35.

21. Ferracane JL. Hygroscopic and hydrolytic effects in dental polymer networks. Dent Mater. 2006; 22: 211-22.

22. Versiani MA, Carvalho-Junior JR, Padilha MIAF, Lacey S, Pascon EA, Sousa-Neto MD. A comparative study of physicochemical properties of AH PlusTM and Epiphany TM root canal sealants. Int Endod J. 2006; 39: 464-71.

23. Carvalho-Junior JR, Correr-Sobrinho L, Correr AB, Sinhoreti MA, Consani S, Sousa-Neto MD. Solubility and dimensional change after setting of root canal sealers: a proposal for smaller dimensions of test samples. J Endod. 2007; 33: 1110-6.

24. Resende LM, Rached-Junior FJA, Versiani MA, Souza-Gabriel AE, Miranda CE, Silva-Sousa YT et al. A comparative study of physicochemical properties of AH Plus, Epiphany, and Epiphany SE root canal sealers. Int Endod J. 2009; 42: 785-93.

25. Johns JI, O'Donnell JN, Skrtic D. Selected physicochemical properties of the experimental endodontic sealer. J Mater Sci Mater Med. 2010; 21: 797-805.

26. Francisconi LF, de Freitas AP, Scaffa PM, Mondelli RF, Francisconi PA. Water sorption and solubility of different calcium hydroxide cements. J Appl Oral Sci. 2009; 17: 427-31.

27. Baldi JV, Bernardes RA, Duarte MAH, Ordinola-Zapata R, Cavenago BC, Moraes JCS, et al. Variability of physicochemical properties of an epoxy resin sealer taken from different parts of the same tube. Int Endod J. 2012; 19: 1-6.

28. Loushine BA, Bryan TE, Looney SW, Gillen BM, Loushine RJ, Weller RN, et al. Setting properties and cytotoxicity evaluation of a premixed bioceramic root canal sealer. J Endod. 2011; 37: 673-7. 